University of Warwick institutional repository: http://go.warwick.ac.uk/wrap This paper is made available online in accordance with publisher policies. Please scroll down to view the document itself. Please refer to the repository record for this item and our policy information available from the repository home page for further information.

To see the final version of this paper please visit the publisher's website. Access to the published version may require a subscription.

Author(s): Jonathan Gardner and Andrew Oswald

Article Title: How is mortality affected by money, marriage, and stress?

Year of publication: 2004

Link to published version:

http://dx.doi.org/ 10.1016/j.jhealeco.2004.03.002

Publisher statement: None 


\title{
How is Mortality Affected by Money, Marriage and Stress?
}

\author{
Jonathan Gardner \\ Watson Wyatt LLP \\ Reigate \\ Surrey \\ RH2 9PQ \\ UK
}

\author{
Andrew Oswald ${ }^{\mathrm{i}}$ \\ Department of Economics \\ Warwick University \\ Coventry \\ CV4 7AL \\ UK
}

Revised Version ${ }^{i i}$

March 2004

${ }^{\mathrm{i}}$ Corresponding author. Tel.: +44 (0) 247652 3510; Fax: +44 (0) 2476523032

Email address: andrew.oswald@warwick.ac.uk (A. Oswald)

ii This replaces an earlier version entitled "Is it money or marriage that keeps people alive?". 


\begin{abstract}
It is believed that the length of a person's life depends on a mixture of economic and social factors. Yet the relative importance of these is still debated. We provide recent British evidence that marriage has a strong positive effect on longevity. Economics matters less. After controlling for health at the start of the 1990s, we cannot find reliable evidence that income affects the probability of death in the subsequent decade. Although marriage keeps people alive, it does not appear to work through a reduction of stress levels. Greater levels of psychological distress (as measured by General Health Questionnaire stress scores) cannot explain why unmarried people die younger. For women, however, we do find that mental strain is dangerous. High GHQ stress scores help to predict the probability of an early death.
\end{abstract}

Keywords: Mortality, health, income and marriage.

JEL Classifications: I12, J12. 


\section{Introduction}

The epidemiological evidence suggests that the length of a person's life depends on a mixture of economic and social factors. Yet their relative importance is still debated. For all sorts of reasons, including the appropriate design of economic and social policy, it is important to understand which forces are correlated with longevity and by what means they prolong life.

The paper explores these issues by using recent longitudinal data from the British Household Panel Survey. Panel data have the crucial advantage that it is possible to control for health at the start of the period. Our study has the additional advantage of being able to control for a rich set of health controls, which include measures of psychosocial distress. We focus on individuals aged over 40 at the beginning of the 1990s and estimate equations for the probability of death over the subsequent decade. Hence, our study ignores mortality in the young and our discussion is only germane to the mortality experiences of the middle-aged and elderly. The focus of our paper is then threefold: (1) to explore whether money or marriage keeps people alive; (2) to examine the relationship between stress levels and later mortality; and (3) to examine whether stress levels can help explain the effects of income and marriage upon longevity.

The findings seem of interest. To our surprise, we can detect only minor effects from economics, with income playing little role once we enter suitable controls for initial health status. Marriage, by contrast, has a large effect on mortality risk, even after controlling for a set of health controls (including measures of psychological distress). The observed measures of stress appear uncorrelated with subsequent male mortality, though they do predict female longevity. 


\section{Previous research}

\subsection{Socio-economic status, health, and mortality}

In pioneering work, Marmot, Shipley and Rose (1984) reported results for the Whitehall study. Here 17,000 British male civil servants, aged between 40 and 64, were interviewed in the late 1960s and their mortality recorded over the following 10 years. The men were classified according to employment grade and a steep inverse relation between grade and mortality was observed. Men working in the lowest grade were observed to have death rates some three times those of workers in the highest grade. Even after controlling for age and observed health factors (such as smoking, obesity and exercise) the relationship between mortality and employment status remained.

Marmot et al (1991) updated these results with a second study (Whitehall II) undertaken in the late 1980s. The authors here studied the relationship between morbidity and employment grade for approximately 10,000 civil servants, both male and female, aged between 35 and 55. Workers with lower socio-economic status were more likely to suffer from illnesses and to have low self-reported health status and less likely to exhibit 'healthy' behaviour. Kuh and Wadsworth (1993) instead examined the relationship between parental socio-economic status and adult health in a cohort of over 3,000 British men and women aged 36 years. Parental social class and childhood health were both found to be strongly predictive of health status at age 36, even after controlling for current economic status.

Similar evidence has been reported for the United States. Duleep (1986) examined the relationship between income and mortality using data on white males, aged 35 to 65, drawn from the 1973 Current Population Survey (CPS). Income displayed diminishing marginal returns in the way in which it reduces mortality: the 
gains from income were particularly pronounced for the very poor. ${ }^{1}$ McDonough et al (1997), who examined the Panel Study of Income Dynamics (PSID), observed similar results. Persistent low income was found to be an especially good predictor of early mortality, but income instability was also an important factor amongst middle-income households.

Wolfson, Rowe, Gentleman, and Tomiak (1993) analysed nearly 550,000 administrative records from the Canada Pension Plan in a longitudinal analysis of male mortality after age 65. They found that higher earnings in late middle age (age 45 to 64 ) were associated with significantly lower mortality at older ages (65 to 74); the survivor probability was 0.740 among those in the lowest earnings quintile and 0.807 for those in the highest income quintile. Nevertheless, there was no direct information relating to health status beyond a disability indicator, and there were no indicators of socioeconomic characteristics other than marital status and income.

Moore and Hayward (1990) studied the National Longitudinal Study (NLS) of Mature Men, where a cohort of American men aged 55 or more were followed over the period 1966 to 1983 . After controlling for age, education, race, marital status, income and health status, the authors showed that substantial differences in mortality rates by lifetime (longest) occupation remained. In contrast, the independent effect of occupation in the last job was limited and the effect of income, whilst negative, was only on the border of statistical significance. Menchik (1993) used the same data to

\footnotetext{
${ }^{1}$ It has long been recognised that there is also a negative association between income inequality and aggregate health outcomes (Rodgers, 1979, Le Grand, 1987). Wilkinson (1996) has argued this reflects causation and that inequality leads to poor health. Recent research has, however, raised doubts over this assertion. Gravelle (1998) shows that the observed negative relation can result from aggregation bias, even when there is no relation between health and inequality, if individual health exhibits diminishing returns to individual income. Gravelle, Wildman and Sutton (2002) cast doubt on the original aggregate evidence and show results are sensitive to how inequality is measured and to which functional form is specified. At the individual level, Daly et al (1998) find the association between inequality and health is not strong. Lynch et al (2001) examine the potential psychosocial pathways by which inequality could adversely impact on health, and find little evidence of a relationship with health
} 
examine racial differences in mortality rates. Black men were found to have substantially raised mortality rates (equivalent to five years of increased age) relative to whites. This was attributed to the lower levels of income and wealth, and greater experience of poverty, within the black population.

Feldman et al (1989) and Lahelma and Valkonen (1990) measured socioeconomic status by education, and once again observed an inverse relation with mortality. However, where comparisons are possible, income or wealth appear to be more powerful predictors of mortality risk (see Duleep, 1986, and Menchik, 1993). Finally, Iversen et al (1987), Moser et al (1984), Morris et al (1994) and Martikainen and Valkonen (1996) demonstrate that individuals who experience unemployment are likely to experience reduced longevity than comparable individuals who are continuously employed.

Whilst the correlation between low socio-economic status and poor health is well documented, few studies have addressed to what degree the relationship is truly causal. If low income is associated with reduced access to or quality of medical treatment, or if low-income workers are exposed to greater occupational risk factors, socio-economic status may have a causal impact upon health. Alternatively, the correlation between health and wealth may reflect rational decision-making by consumers. Individuals who expect a long duration of life may accumulate assets to finance their retirement, whilst those with a limited life expectancy may run down their wealth. Economic theory also predicts that those in good health will have higher labour force participation rates and be more productive, hence earning higher wages (Luft, 1975, and Lee, 1982). The direction of causation then can run from health to income. Other genetic and behavioural factors may cause a positive association 
between health and wealth (e.g. common tastes for work and good health). Smith (1999) contains a comprehensive discussion of these issues.

Ettner (1996) addresses the issue of causality by using an instrumental variable model -- where income is instrumented by the state unemployment rate, the respondent's work experience and parental education, and the spouse's education, experience and parental education. These variables are assumed correlated with income but uncorrelated with health. The estimated income effect is, in nearly all cases, of larger magnitude than traditionally observed, which is consistent with a causal role for income upon health.

Adams et al (2003) adopt an alternative approach. The authors test for the absence of effects of socio-economic status upon innovations in health in a sample of Americans aged 70 or more in 1993 who were followed until 1998. The hypothesis of non-causality will, in general, only be accepted if no causal link is present and there are no persistent hidden factors that mould both initial status and subsequent innovations. Consistent with previous evidence, a statistically significant positive association between health and socio-economic status was initially observed. Yet, when the incidence of new health problems -- conditioning on initial health conditions -- were instead examined, the authors concluded that there is no causal link from wealth to mortality or the sudden onset of health conditions.

The evidence then suggests that the observed association between socioeconomic status and mortality may not result from a direct causal link, but rather that it indirectly reflects variation in health conditions. These differences in health status could themselves result from earlier differences in income accumulation, so indirect avenues of causation may still exist, or unobserved behavioural or genetic factors 
(see Adda, Chandola and Marmot, 2003). By contrast, even after controlling for initial health, there does remain an association between wealth and the incidence of gradually worsening health conditions and mental problems. The cross-country evidence (Adda et al, 2003) would seem to favour behavioural factors as the route of this correlation.

As Deaton (2003) states "it is clear that there are influences between income and health that run in both directions, and that, in some cases, the lags can be as long as a human lifetime". In such a setting, identifying causal relationships is difficult and it is perhaps unsurprising the evidence remains mixed in this area.

\subsection{Marriage, health, and mortality}

That mortality rates are lower for married individuals has long been known (one of the first examples is the study of Farr, 1858). Hu and Goldman (1990) observe that the relationship holds in 16 developed countries. Manor et al (2000) note the same pattern for Israel, as does Rahman (1993) for Bangladesh. The reasons for this excess mortality among the unmarried are still subject to debate. ${ }^{2}$

Why might marriage be protective? First, it may reduce stress and stressrelated illness (perhaps as a result of greater social integration). Second, marriage may encourage healthy types of behaviour, and discourage risky or unhealthy ones (drinking, substance abuse, etc). A spouse also makes it more likely that the individual receives adequate care in times of illness. Finally, marriage may increase material well-being, not only by increasing family income, but also as a result of economies of scale from pooling resources and the specialisation of household tasks.

\footnotetext{
${ }^{2}$ For a more detailed description of the literature studying the relationship between marriage, health and mortality see Wilson and Oswald (2002).
} 
Alternatively, there may be no beneficial effects of marriage upon health, but rather it may simply be that more healthy individuals are 'selected' into marriage.

Gove (1973) argues that the reduced mortality rates of the married can, in part, be attributed to the psychosocial status of marriage in society and the greater social isolation of unmarried individuals. As with mortality, married individuals show favourable psychological well-being and mental health, and the specific types of mortality with which marriage are most strongly related are those that are strongly linked to social factors (e.g. suicide, murder, accidental deaths). Rodgers (1995) offers equivalent evidence using a matched case-control methodology, whilst House et al (1982) find that individuals with extensive social networks have lower mortality rates, though an independent effect of marriage remains. Schoenbach et al (1986), however, suggest that the beneficial effects of social networks are limited to elderly people who have few other social ties.

$\mathrm{Hu}$ and Goldman (1990) argue that if more healthy individuals are selected into marriage, then mortality rates among the unmarried will be lower where these groups form a larger proportion of the population. In this case, where fewer people are married, the stock of single individuals in the population will have, on average, better health, and the aggregate mortality differential will be lower. Whilst the evidence is generally supportive, Goldman (1993) suggests that the conditions for such evidence to be conclusive are stringent, and that aggregate data produce unpredictable patters in relative mortality rates.

Possibly the largest study is that of Wolfson, Rowe, Gentleman, and Tomiak (1993), who studied some 550,000 individuals who were members of the Canada Pension Plan in a longitudinal analysis of male mortality over the ages 65 to 74. Married males were found to have lower mortality rates and this applied at all 
retirement ages and was robust to the inclusion of measures of lifetime income. However, there was only very limited information on health status (a single disability indicator), and whilst the finding is robust to income, the avenues through which the correlation occurs are not clear.

Lillard and Waite (1995) examine the extent to which the beneficial effects of marriage can be accounted for by financial wealth, living arrangements, and marital history. For women, but not for men, much of the benefit of marriage is found to result from increased financial security. For both men and women, the longevity gain from marriage is also found to cumulate with the marriage's duration.

Lillard and Panis (1996) note that if marriage does have protective effects then those individuals in poor health have a larger incentive to marry. This kind of adverse selection acts counter to matching selection, whereby the healthy marry. The authors find that healthy men are both less likely to marry and to marry later. Nevertheless, unobserved factors lead to a positive association between good health and marriage, and overall this positive effect is found to dominate. The excess mortality of divorced men is then shown to be largely associated with their inferior health; but, both for the widowed and never married, health status has little role in explaining their excess mortality. In contrast, for the UK, Ben-Shlomo et al (1993) discover that initial health and socio-economic status largely explain the inferior mortality rates of the never married, but not those of the separated or divorced. Murray (2000) finds that even after controlling for health in early adulthood, marriage still significantly reduces subsequent mortality.

In summary, while there is substantial evidence that marriage is associated with reduced mortality risk, questions remain as to why. 


\section{Data}

The British Household Panel Survey is a nationally representative sample of more than 5,000 British households, containing over 10,000 adults (see Taylor, 2002). Respondents have been interviewed annually from 1991 to 2001. If an individual leaves their original household, all adult members of their new household are also interviewed. If the household moves location, and remains within the British Isles, they are interviewed at their new location. An indicator records whether the respondent exits the survey due to death. Individuals who subsequently refuse to respond to the full survey are contacted in subsequent waves in an attempt to obtain basic information as to their status. The BHPS also contacts death registers to ascertain whether non-responders have subsequently become deceased.

Attention is here restricted to respondents aged over 40 at the time of interview in 1991 and whose mortality status is known in the year 2001. Our independent variables are measured in 1991, with the exception of household income, which is calculated as mean income from the 1991 and 1992 waves. This two-year averaging should be less prone to measurement error and be a better approximation of permanent income than a single-year income variable. ${ }^{3}$ The estimation sample then records mortality for the period 1993 to 2001 . The sample with non-missing values of covariates contains some 1646 men and 2049 women, with 356 and 385 observed deaths. The mortality rates are 21.6 percent and 18.8 percent respectively.

\section{Econometric Approach}

\footnotetext{
${ }^{3}$ The two-year average was here found to provide a better fit for mortality than a single-year income measure.
} 
Mortality risk is modeled as a function of personal characteristics (age, education, and marital status), income (household income per adult-equivalent) and health (whether a smoker and self reported health status). Throughout the paper marriage is measured in the formal sense and does not include co-habitation per se. Separate equations are estimated for males and females. Mortality risk for individual i is expressed:

$$
m_{\mathrm{i}}^{*}=y_{i}^{\prime} \delta+x_{i}^{\prime} \beta+z_{i}^{\prime} \lambda+u_{i}, \quad \mathrm{i}=1, \mathrm{~K}, \mathrm{n} .
$$

where $\mathrm{m}^{*}$ is the latent mortality variable, $\mathrm{y}$ is income, $\mathrm{x}$ the vector of personal characteristics, $\mathrm{z}$ the vector of health characteristics, $\mathrm{u}$ the conformable error term with mean zero and constant variance, and $\varphi, \beta$ and $\gamma$ the parameters to be estimated. The quantity $\mathrm{m}^{*}$ can be interpreted as a stock of health which, when negative, results in death. The probability that, over the sample period, individual i dies, is given by:

$$
\operatorname{Pr}(m=1)=F\left(y_{i}^{\prime} \delta+x_{i}^{\prime} \beta+z_{i}^{\prime} \lambda\right), \quad \mathrm{i}=1, \mathrm{~K}, \mathrm{n} .
$$

Previous research has shown the log odds of mortality to be approximately linear in age for those aged over 30 (Thatcher, 1999). This corresponds to the case where $F($.$) is the logistic distribution function and parameters are estimated by$ maximum likelihood.

\section{Results}

Tables 1a and 1b present the simplest results, and examine the influence of wealth, health and marriage upon mortality, for males and females respectively. In each case, the average marginal effects of the estimates are reported.

In column one of Table 1a, for the British Household Panel, household income enters the mortality equation as a categorical variable capturing the quintiles in income. For men, mortality risk (between the years 1993 and 2001) is observed to be 
monotonically decreasing in income (in 1991). A male in the lowest income quintile in 1991 is 8.5 percent more likely to die over the period 1993-2001 than an otherwise similar male in the highest income quintile. For men in the second lowest income quintile, the comparable figure is 4.5 percent. As with previous studies, we find income is most strongly related to mortality for those on low incomes. ${ }^{4}$ Estimates are not though particularly well-determined. Only the marginal effect of lowest income quintile achieves conventional levels of statistical significance. Column two, of Table 1a, instead examines log household income per adult household member. The coefficient on log income is estimated to be negative and is statistically significantly different from zero. Calculated at the mean, the marginal effect of a one-unit increase in log household income per head is estimated to reduce the mortality risk by -4.5 percent. Alternatively, moving from one standard deviation below mean income to one standard deviation above is predicted to reduce the mortality rate by -5.6 percent. Hence there is some evidence here that money helps keep people alive.

For women, in column one of Table 1b, when household income quintiles are included in the mortality equation, we find little evidence of a reliable link between household income and death rates. The relationship between income and mortality does not follow a clear pattern and there is no statistical difference in mortality rates between women in the lowest and highest income quintiles. In column two, of Table 1b, when log household income per adult household member enters the mortality equation, the estimated coefficient is relatively small and not statistically significantly different from zero. In contrast to men, where income predicts quite large reductions in mortality risk, the correlation between income and mortality amongst women is, here, largely absent.

\footnotetext{
${ }^{4}$ We cannot, here, distinguish between absolute and relative income effects upon mortality.
} 
Marriage is found to be associated with substantially lower rates of mortality, for both men and women. Married men are predicted to be some -7.2 percent less likely to die over the period than unmarried men. For women, the effect is smaller. ${ }^{5}$ Women married in 1991 are approximately -4.1 percent less likely to die over the period 1993 to 2000 than otherwise similar unmarried women.

Unsurprisingly, age has a very strong influence upon the probability of survival over the period. An extra year of age increases mortality risk by approximately 1.3 percent for men, and 1.2 percent for women. Finally, more educated men and women have lower rates of mortality. For men, lower mortality rates are observed for individuals with degree level qualifications. A male educated to degree level is predicted to have a 5 percent lower mortality risk than men with no formal qualification. Nevertheless, the estimate is not statistically well determined. For those men with intermediate qualifications or no formal qualifications, mortality rates are similar. For women, in contrast, the gains from education are similar for those with degree level or intermediate qualifications, with approximately a 3 percent lower probability of mortality in each case. Again, however, the coefficients are not statistically different from zero. ${ }^{6}$

The results discussed so far have been based on equations in which health dummy variables are excluded. To what extent can differences in health explain the observed patterns in mortality rates? Controls for self-reported health ${ }^{7}$ and smoking are added, in later columns of Tables $1 \mathrm{a}$ and $1 \mathrm{~b}$, to the mortality equation. For males, in Table 1a, the parameters upon the income variables are now attenuated by nearly a

\footnotetext{
${ }^{5}$ Gove (1973) and Lillard and Waite (1995) similarly observe larger beneficial effects for males.

${ }^{6}$ If we omit education from the mortality equation previous results are substantially unchanged.

${ }^{7}$ Idler and Kasl (1991) find self-reported measures of health status to be good predictors of mortality, even after adding stringent controls for the presence of health problems, physical disability, and biological or life-style risk factors. Subjective health questions may then be informative for life expectancy information, even in the presence of detailed assessments of health.
} 
half, and are no longer statistically different from zero. (See columns IV to VI of Table 1a.) As with Adams et al (2001), once we condition upon initial health, we do not find strong evidence of a causal link from income on to mortality. This suggests that the beneficial effects of money are to a large degree felt, indirectly, via improved health early on. Or, to put it differently, income has no immediate effect on mortality risk, though it may operate with a long lag through an effect on health. Whether the links between income, or education, and health reflect a direct effect of economic prosperity upon health, health onto wealth, or a correlation between unobserved factors that cause both good health and higher incomes, is, however, unclear.

For women, the effect of income on mortality was previously limited, and the addition of controls for health further attenuates it. An equivalent pattern is observed with respect to education. Controlling for existing health status weakens the estimated education effects by up to a half, and they are no longer statistically different from zero.

What of the unmarried? Whereas a large part of the beneficial effects of income upon mortality, for men, are found to accrue from improved health, only to a limited degree do differences in health explain the excess mortality of the unmarried. The addition of health controls reduces the estimated marginal effect of marriage from -7.2 percent to -6.3 percent. For women, controlling for health reduces the marginal effect upon marriage from -4.1 percent to -3.4 percent. For both men and women, mortality rates remain lower for the married, with the effect statistically significant different from zero for all reasonable p-values for men and at the 6 percent level for women. There are beneficial effects of marriage, upon mortality risk, that are independent of the respondent's initial health. 
Marriage thus keeps you alive, and the effect is large. After controlling for health status, a married male is predicted to be -6.3 percent less likely to die over the period 1993 to 2000 . The excess mortality of the unmarried is here similar to that of a smoker (5.0 percent). For women, being a smoker increases the risk of death by 5.2 percent, while being married reduces the risk of mortality by -3.4 percent.

To summarise, for men, if initial health in 1991 is not held constant, greater income is associated in BHPS data with reduced risk of mortality. This is, in large part, due to the positive association between health and economic prosperity. Yet in British Household Panel data there seems a much smaller effect of income upon male mortality once initial health is controlled for; indeed, although it might be unwise to take our finding here literally, it is not possible to reject the null hypothesis that the influence of income is zero. For women, the effect of household income upon mortality is always slight. Within the BHPS, the married, both male and female, are at significantly lower risk of mortality. Whilst the married are healthier (according to their self-reported health status), this is found to offer only a partial explanation for their reduced mortality rates. Significant protective effects from marriage remain.

The impact of employment history upon mortality risk, for men, is analysed in columns three and six of Table 1a. An additional year of unemployment (compared to being employed for that year) is predicted to increase the risk of mortality by 1.4 percent, and this effect is statistically different from zero. Unemployment is thus, for men, associated with greater risk of early death. In part, this may be due to the reduced income, and inferior health (both physical and psychological), as a result of joblessness. Nevertheless, in column six of Table 1a, we observe an independent effect of unemployment even after controlling for both income and health status, and an additional year of unemployment is predicted to raise the probability of death by 
1.3 percent. The effect continues to be well determined. ${ }^{8}$ For women, unemployment experience is not found to be positively associated with mortality. This may partly reflect the sample of middle aged and older women analysed.

In further results (available from the authors upon request) we investigated in detail the influence of the various unmarried states (never married, separated or divorced, and widowed) upon mortality, for both males and females. For males, relative to being married, being never married in 1991 increases the risk of death between 1993 and 2001 by a remarkable 10.2 percent, being separated or divorced in 1991 by 10.3 percent, and being widowed by 9.3 percent. $^{9}$ Controlling for initial health status attenuated the magnitude of these estimates somewhat, but the effects still remained substantial and statistically robust. By contrast, Ben-Shlomo et al (1993) conclude, using British data, that initial health and socio-economic status largely explain the inferior mortality rates of the never married, but not those of the separated or divorced. For the US, Lillard and Waite (1995) observe the same kinds of effects for all unmarried groups, whilst Lillard and Panis (1996) find the excess mortality of divorced men is largely associated with their inferior health, but, both for the widowed and never married, large effects continue to hold.

Interestingly, women who are never married are at no greater risk of mortality than those women who are married in 1991. Yet women who are widows in 1991 are 5.8 percent more likely to die between 1993 and 2001 than an otherwise similar married woman. After controlling for health variables, this falls to 5.3 percent. In both cases the estimates are statistically significantly different from zero. Women who are separated or divorced in 1991 are also disadvantaged; they have a 4.8 percent

\footnotetext{
${ }^{8}$ The labour market history measures are calculated from recall data, and are then prone to recall bias. The distinction between unemployment and being out of the labour force may then be subject to some error.

${ }^{9}$ Results are from equations where income if entered in log form.
} 
greater risk of mortality; and after controlling for health status this falls to some 3.1 percent but is no longer statistically well-determined. For the US, Lillard and Waite (1995) document a large effect upon mortality for females who are separated or divorced. Here it is marital dissolution that raises the risk of mortality. Those women who never marry are found to be at no greater mortality risk than married women.

The longer the number of years spent as a single, separated, divorced or widowed man, the higher the risk of mortality. In all three cases these effects are statistically robust, and with regards to time spent separated or divorced and years widowed the effects remained robust after controlling for initial health status. For men, the benefits of marriage cumulate over time. In part this is due to the superior health of those individuals with marriages of longer duration, but substantial benefits remain even after controlling for health at the start of the 1990s. For women, by contrast, the number of years spent single has no strong impact upon mortality risk, when compared to being married. Each extra year of being separated or divorced (relative to being married) or widowed is found to raise mortality risk, but only the time spent widowed is statistically different from zero after controlling for health status. In part this is due to their inferior health, which itself could reflect a cause or consequence of marital dissolution. Females who have been widowed for a longer duration are also found to be at a greater risk of mortality, but here health status is not found to play a large role.

Why does marriage help to keep people alive? One possibility is that it may reduce stress and stress-related illness. Indeed we know that married men and women tend to have lower stress levels (see Wilson and Oswald, 2002). Nevertheless, this need not explain why marriage is apparently beneficial for longevity. 
The hypothesis that the causal chain is from improved psychological wellbeing on to longer life is investigated in more detail in Tables 2a and Table 2b. In the tables we examine the influence of a number of measures of psychological distress on mortality risk. The BHPS contains a standard measure of mental strain, drawn from the General Health Questionnaire (GHQ). This method has been used extensively by medical researchers and psychiatrists and, whilst unfamiliar to some economists, GHQ scores are arguably the most widely used, questionnaire-based, way of measuring mental stress.

The GHQ Questionnaire contains twelve questions, each one of which is scored on a four-point scale from 0 to 3 :

Have you recently:

1. Been able to concentrate on whatever you are doing?

2. Lost much sleep over worry?

3. Felt that you are playing a useful part in things?

4. Felt capable of making decisions about things?

5. Felt constantly under strain?

6. Felt you could not overcome your difficulties?

7. Been able to enjoy your normal day-to-day activities?

8. Been able to face up to your problems?

9. Been feeling unhappy and depressed?

10. Been losing confidence in yourself?

11. Been thinking of yourself as a worthless person?

12. Been feeling reasonably happy all things considered? 
We focus upon questions: (3) playing a useful role, (5) constantly under strain, (9) unhappy or depressed, and (11) believe in self-worth. ${ }^{10}$ These questions are transformed from their 4-point scale into dichotomous indicators of whether the individual responds negatively (1) or not (0).

We also used responses to all twelve questions to form a dichotomous indicator of those likely to be at risk of psychiatric morbidity. This is commonly classified as those individuals who respond to at least four, of the twelve, GHQ questions in one of two negative response categories (see Bowling, 1997). Hence, the four individual measures of stress or distress we study are components of our overall mental strain indicator. We do not, here, attempt to re-calibrate the 'high stress' indicator for such compositional effects.

For males, in Table 2a, we observe no discernible evidence of a correlation between the five stress measures and subsequent male mortality. Moreover, the estimated effect of marriage upon mortality is largely unchanged as a result of controlling for these measures of stress. For men, elevated stress scores for the unmarried do not appear to offer a convincing explanation for their inferior longevity, relative to the married.

For females, by contrast, in Table $2 \mathrm{~b}$, we find evidence of a statistically robust positive association between measures of distress and subsequent female mortality. Those females whom we describe as indicating high stress in 1991 (in column two) are 6.6 percent more likely to be deceased by 2003. Similarly, those females who respond negatively to the questions as to whether they are playing a useful role or whether they believe in their self-worth are 10 percent more likely to die over the period. Women who are unhappy or depressed are 4 percent more likely to be

\footnotetext{
${ }^{10}$ Results for all measures are available from the authors upon request.
} 
deceased in 2003, whilst those who feel constantly under strain are 2.5 percent more likely. The latter effect is not, however, statistically different from zero.

Nevertheless, whilst stress levels are found to have some explanatory power with respect to female longevity, they do not here explain the beneficial effect of marriage - the coefficient on marriage remains remarkably stable throughout the columns in Table 2b. Marriage does not appear to prolong the longevity of women by reducing psychological strain.

One concern is that the selection of a subset of GHQ questions has skewed the ensuing results. To a degree, this is likely to be true, as we selected those questions we felt most likely to capture mental strain and low esteem. Nevertheless, it is reassuring that when we examine the remaining eight questions, similar patterns are found. In all eight cases the strain variable enters positively and in four cases the results are statistically robust. ${ }^{11}$

Hence, for women, there is evidence that heightened stress levels do raise subsequent mortality risk. Yet, such a finding could be a result of omitted health characteristics. Results may then reflect a respondent's ill-health, which is associated with both reduced longevity and heightened stress levels. In Tables 3a and 3b we check for this possibility by adding controls for health status to the mortality equation. In columns one to three we add controls for subjective health status and whether the respondent is a smoker, whilst in columns four to six we replace subjective health status with the number of reported health problems. ${ }^{12}$ This was motivated by a

\footnotetext{
${ }^{11}$ Hence, to summarise results, the following 7 questions show statistically significant positive associations with mortality: ability to concentrate, playing a useful part in things, enjoy your normal day-to-day activities, face up to your problems, unhappy and depressed, losing confidence in yourself, and thinking of yourself as a worthless person? The following 5 questions show positive, but statistically weak, effects: lost much sleep over worry, capable of making decisions about things, constantly under strain, could not overcome your difficulties, reasonably happy all things considered. 12 These conditions included problems with arms, legs, and hands, sight, hearing, skin conditions/allergies, chest/breathing, heart/blood pressure, stomach or digestion, diabetes, anxiety or depression, alcohol or drugs, epilepsy, or migraines.
} 
concern about potential collinearity between subjective health status and the mental distress measures -- that poor subjective health status may reflect stress as much as cause it.

For males, in Table 3a, we again find no evidence that our measures of psychological distress raise subsequent mortality rates. Indeed, somewhat perplexingly, the sign of the coefficients are negative, suggesting, for men, that mental strain lowers mortality risk, conditional on health status. In one case the effect is even statistically significantly different from zero. It is not clear why we should observe such a pattern. One concern is that this finding did not appear in the mortality equations that omitted the health controls - so they may be being driven by collinearity between health status and mental strain. When we enter the less subjective measures of health status (the number of health problems), the stress measures nevertheless remain negative, though not statistically significantly different from zero. In Table 4a, we examine how the measure 'playing a useful role' enters the mortality equation for sub-samples of respondents. In all columns, the measure enters negatively but is never statistically different from zero. The benefits of marriage are greatest amongst those of low socio-economic status (those with no formal educational qualifications or below median income). Similarly, whilst the income variable is in most cases not statistically significantly different from zero, we find evidence of a statistically robust effect for those people with low education.

For females, in Table 3b, the addition of health controls (either subjective health status or the number of health problems) attenuates the effect of the high stress indicator and the measures 'playing a useful role' and 'believe in self-worth' but they largely remain robust. For the remaining measures of stress, ‘constantly under strain’ and 'unhappy or depressed' the results are not statistically different from zero. It is 
potentially instructive that those measures that are most closely related to mortality are related to esteem, whereas variables that capture measures of depression appear less important. In Table 4b we examine whether the results with regards 'playing a useful role' are robust across sub-samples of individuals. In the majority of cases this is true, with the notable exception that for women living in above median income households we do not observe a strong effect. Therefore, the relationship between mortality risk and stress or (esteem) appears to be one predominantly felt by those on low incomes. Consistent with previous evidence, household income itself largely fails to exert an influence upon female longevity. It could be that men are more concerned than women about the status that money buys, but this can be only a conjecture.

Some recent epidemiological papers have also sought to examine the links between high stress (low self-esteem) and mortality risk. In a US study, Whooley and Browner (1998) examine some 7500 women aged 67 or above. They find that a high score of depressive symptoms is correlated with an increased mortality rate. Mortality during 7-year follow-up varied from 7\% in women with no depressive symptoms to $17 \%$ in those with 3 to 5 symptoms to $24 \%$ in those with 6 or more symptoms of depression. These results remain even after adjusting for many diseases, smoking, perceived health and cognitive function. The authors cannot, however, determine whether depressive symptoms are a marker for, or a cause of, reduced longevity. Fredman et al (1999) examined the association between depressive symptoms and mortality among 764 white women aged 65 years or more. Only weak associations between stress and mortality were observed and depressive symptoms were associated with mortality only among women in poor health.

Huppert and Whittington (1995) analysed such issues in a representative sample of nearly 6100 adults, aged 18 or more. Respondents whose GHQ score was 
above the conventional threshold were $60 \%$ more likely to die over the 7-year interval than respondents whose GHQ score was below threshold (for both men and women). The differences were statistically significant for both sexes when the effects of age, physical disorder, social class and smoking behaviour were taken into account. The findings from this general population study suggest it is not only psychiatric disorders, but also psychiatric symptoms, which are associated with subsequent mortality.

For the UK, Macleod et al (2001) examined the relationship between psychological stress and cause-specific mortality. As in our results for men, the authors found stress to be apparently protective for all-cause mortality and for most cause-specific mortality risks. This was ascribed to the fact that, in the sample they studied, males that were at higher risk of stress were also those of higher socioeconomic status, so the stress results captured the impact of socio-economic status. The authors then suggest that correlations between stress and health may be spurious if the researcher does not have adequate controls for material background. The work of May et al (2002) discusses recent international evidence on the link between psychological stress and the risk of coronary heart disease and stroke. Amongst a sample of some 2200 men aged 45 to 59, the authors found significant evidence of an association between prior stress (depression) and the subsequent risk of a fatal ishemic stroke, even after controlling for a comprehensive list of risk factors and social class.

Recent research by Martikainen et al (2003) instead analysed GHQ as a dependent variable, examining the influence of income and wealth on GHQ depression and self-reported health status using the Whitehall II Study. ${ }^{13}$ Echoing the results we observe, the authors initially observe large differences in morbidity rates

\footnotetext{
${ }^{13}$ The sample was re-interviewed between 1997 and 1999.
} 
according to income and wealth, for both males and females. However, after controlling for initial health, the relationship between household income and morbidity is attenuated by up to 40 percent. For wealth the figure is smaller, at 30 percent. Adjusting for other socio-economic factors further attenuated their results. Nevertheless, both associations remain statistically robust. Hence, the authors conclude that the associations between income and morbidity are largely accounted for by pre-existing health and other measures of social position.

One final possibility we investigate is that our sample of older individuals makes likely a small estimated impact of income on mortality - if poorer individuals had already died before they could enter the sample. We may then underestimate the influence that money has on the risk of death.

This is explored in Tables $5 \mathrm{a}$ and $5 \mathrm{~b}$. We examine mortality equations for those respondents aged between 40 and 65 in 1991, for males and females respectively. ${ }^{14}$ If selection bias were important for our results, we would expect parameter estimates to be substantially altered from those observed previously. For both males and females, however, the pattern of results with respect to income is repeated. Once initial health is held constant, there is no strong association between income and mortality risk. Similarly, the results with regards to the stress/esteem variables are largely as we observed for the full sample. Interestingly, for marriage we no longer observe a robust effect upon female longevity - the coefficient is attenuated and no longer statistically significantly different from zero. The beneficial effects of marriage are then, here, largely associated with older women. For men, by contrast, the benefits of marriage on longevity are again apparent. 


\section{Conclusion}

Although it is known that the length of a person's life depends on a mixture of economic and social factors, the relative importance of these is still debated. We study this by using longitudinal British data from the British Household Panel Survey. Longitudinal data have the advantage that it is possible to control for the individual's health at the start of the survey period.

This paper's results suggest that marriage has a more important effect on longevity than income does. For men, the effect of being married is positive and substantial. For example, it approximately offsets the large negative consequences of smoking. For women, the influence of marriage is smaller, at half the size of the smoking effect.

Exactly how marriage works its magic remains mysterious. Interestingly, our evidence suggests that it is not through lowered stress. The marriage coefficients in our mortality equations remain largely unaffected by the inclusion of GHQ strain variables calculated from the General Health Questionnaire.

Money matters less. Controlling for health at the start of the 1990s, a person's income at the start of our sample period does not seem to affect significantly the risk of mortality during the ensuing decade. It may be that income takes a long time to make a difference, so that health at the start of the 1990s is influenced by the person's economic prosperity much earlier in his or her life. Finally, for men, a history of unemployment contributes to premature mortality. For women, high stress levels (as measured by GHQ stress scores) also raise the risk of death.

\footnotetext{
${ }^{14}$ We now observe 1155 males with a 9-year mortality rate of 9.9\% (114 observed deaths). For females we observe 1355 respondents with a mortality rate of 7.0\% (95 deaths).
} 


\section{Acknowledgements}

We are grateful for useful comments from two referees and from Angus Deaton and George Davey Smith. The Economic and Social Research Council (ESRC) provided research support. The usual disclaimers apply. The British Household Panel Survey data were made available through the UK Data Archive. The data were originally collected by the ESRC Research Centre on Micro-social Change at the University of Essex, now incorporated within Institute for Social and Economic Research. Neither the original collectors of the data nor the Archive bear any responsibility for the analyses or interpretations presented here. 


\section{Bibliography}

Adams, P., Hurd, D., McFadden, D., Merrill, A., Ribeiro, T., 2003. Healthy, wealthy, and wise? Tests for direct causal paths between health and socioeconomic status. Journal of Econometrics 112, 3-56.

Adda, J., Chandola, T., Marmot, M., 2003. Socio-economic Status and Health: Causality and Pathways. Journal of Econometrics 112, 57-63.

Attanasio, O., Emmerson, C., 2001. Differential mortality in the UK. IFS working paper WP01/16. Institute for Fiscal Studies, London.

Ben-Shlomo, Y., Davey Smith, G., Shipley, M., Marmot, M. G., 1993. Magnitude and causes of mortality differences between married and unmarried men. Journal of Epidemiology and Community Health 47(3), 200-205.

Bowling, A., 1997 Measuring Health: A Review of Quality of Life Scales. 2nd ed. Buckingham, UK: Open University Press.

Daly, M. C., Duncan, G. J., Kaplan, G. A., Lynch, J. W., 1998. Macro-to-micro links in the relation between income inequality and mortality. The Millbank Quarterly 76(3), 315-339.

Deaton, A., 2003. Health, Inequality, and Economic Development. Journal of Economic Literature 41(1), 113-158.

Deaton, A., Paxson, C., 2001. Mortality, income, and income inequality over time in Britain and the United States. NBER working paper 8534. NBER, Cambridge Mass.

Duleep, H. O., 1986. Measuring the effect of income on adult mortality using longitudinal administrative record data. The Journal of Human Resources 21(2), 238251.

Ettner, S. L., 1996. New evidence on the relationship between income and health. Journal of Health Economics 15(1), 67-85.

Farr, W., 1858. The influence of marriage on the mortality of the French people, in: Hastings, G. W. (Eds), Transactions of the National Association for the Promotion of Social Sciences. John W. Parker and Son, London, pp. 504-513.

Feldman, J., Makuc, D. M., Kleinman, J. C., Coroni-Huntley, J., 1989. National trends in educational differences in mortality. American Journal of Epidemiology 129(5), 919-933.

Fredman, L., Magaziner, J., Hebel, J. R., Hawkes, W., Zimmerman, S. I., 1999.

Depressive symptoms and 6-year mortality among elderly community-dwelling women. Epidemiology 10(1), 54-9.

Goldman, N., 1993. Marriage selection and mortality patterns: Inferences and fallacies. Demography 30(2), 189-208. 
Gove, W. R., 1973. Sex, marital status, and mortality. American Journal of Sociology 79(1), 45-67.

Gravelle, H., 1998. How much of the relation between population mortality and unequal distributions of income is a statistical artefact? British Medical Journal 314(7128), 382-385.

Gravelle, H., Wildman, J., Sutton, M., 2002. Income, income inequality and health: What can we learn from aggregate data? Social Science and Medicine 54(4), 577-589.

House, J. S., Robbins, C., Metzner, H. L., 1982. The association of social relationships and activities with mortality: Prospective evidence from the Tecumseh community health study. American Journal of Epidemiology 116(1), 123-140.

Hu, Y., Goldman, N., 1990. Mortality differentials by marital status: An international comparison. Demography 27(2), 233-250.

Huppert, F. A., Whittington, J. E., 1995. Symptoms of psychological distress predict 7-year mortality. Psychological Medicine 25 (5), 1073-86.

Idler, E. L., Kasl, S., 1991. Health perceptions and survival: Do global evaluations of health status really predict mortality? Journal of Gerontology 46(2), S55-S65.

Iversen, L., Andersen, O., Andersen, P. K., Christoffersen, K., Keiding, N., 1987. Unemployment and mortality in Denmark, 1970-80. British Medical Journal 295, 879-884.

Kuh, D. J. L., Wadsworth, M. E. J., 1993. Physical health status at 36 years in a British national birth cohort. Social Science and Medicine 37(7), 905-916.

Lahelma, E., Valkonen, T., 1990. Health and social inequities in Finland and elsewhere. Social Science and Medicine 31(3), 257-265.

Le Grand, J., 1987. Inequality in health: Some international comparisons. European Economic Review 31, 182-191.

Lee, L., 1982. Health and wage: A simultaneous equation model with multiple discrete indicators. International Economic Review 23(1), 199-221.

Lillard, L. A., Panis, C. W. A., 1996. Marital status and mortality: The role of health. Demography 33(3), 313-327.

Lillard, L. A., Waite, L. J., 1995. 'Till death do us part: Marital disruption and mortality. American Journal of Sociology 100(5), 1131-1156.

Luft, H. S., 1975. The impact of poor health on earnings. The Review of Economics and Statistics 57(1), 43-57. 
Lynch, J. W., Davey Smith, G., Hillemeier, M., Shaw, M., Raghunathan, T., Kaplan, G. A., 2001. Income inequality, the psycho-social environment and health: Comparisons of wealthy nations. The Lancet 358(9277), 289-304.

Macleod J., Smith G. D., Heslop P., Metcalfe C., Carroll D., Hart C., 2001. Are the effects of psychosocial exposures attributable to confounding? Evidence from a prospective observational study on psychological stress and mortality. Journal of Epidemiological and Community Health 55(12), 878-84.

Manor, O., Eisenbach, Z., Israeli, A., Friedlander, Y., 2000. Mortality differentials among women: The Israel longitudinal mortality study. Social Science and Medicine 51(8), 1175-1188.

Marmot, M. G., Davey Smith, G., Stansfeld, S., Patel, C., North, F., Head, J., White, I., Brunner, E., Feeney, A., 1991. Health inequalities among British civil servants: The Whitehall II study. The Lancet 337, 1387-1393.

Marmot, M. G., Shipley, M. J., Rose, G., 1984. Inequalities in death - Specific explanations of a general pattern? The Lancet, 1003-1006.

Martikainen, P., Adda, J., Ferrie, J. E., Davey Smith, G., Marmot, M., 2003. Effects of income and wealth on GHQ depression and poor self rated health in white collar women and men in the Whitehall II study. Journal of Epidemiological and Community Health 57(9), 718-23.

Martikainen, P. T., Valkonen, T., 1996. Excess mortality of unemployed men and women during a period of rapidly increasing unemployment. The Lancet 348, 909912.

May, M., McCarron, P., Stansfeld, S., Ben-Shlomo, Y., Gallacher, J., Yarnell, J., Davey Smith, G., Elwood, P., Ebrahim, S., 2002. Does psychological distress predict the risk of ischemic stroke and transient ischemic attack? The Caerphilly Study. Stroke 33(1), 5-6.

McDonough, P., Duncan, G. J., Williams, D., House, J., 1997. Income dynamics and adult mortality in the United States, 1972 through 1989. American Journal of Public Health 87(9), 1476-1483.

McFadden, D. F., 1974. The measurement of urban travel demand. Journal of Public Economics 3, 303-328.

Menchik, P. L., 1993. Economic status as a determinant of mortality among black and white older men: Does poverty kill? Population Studies 47(3), 427-436.

Moore, D. E., Hayward, M. D., 1990. Occupational careers and mortality of elderly men. Demography 27(1), 31-53.

Morris, J. K., Cook, D. G., Shaper, A. G., 1994. Loss of employment and mortality. British Medical Journal 308, 1135-1139. 
Moser, K. A., Fox, A. J., Jones, D. R., 1984. Unemployment and mortality in the OPCS longitudinal study. The Lancet, 1324-1328.

Murray, J. E., 2000. Marital protection and marital selection: Evidence from a historical-prospective sample of American men. Demography 37(4), 511-521.

Rahman, O., 1993. Excess mortality for the unmarried in rural Bangladesh. International Journal of Epidemiology 22(3), 445-456.

Rodgers, G. B., 1979. Income and inequality as determinants of mortality: An international cross-section analysis. Population Studies 33(2), 343-351.

Rogers, R. G., 1995. Marriage, sex and mortality. Journal of Marriage and the Family 57(2), 515-526.

Schoenbach, V. J., Kaplan, B. H., Fredman, L., Kleinbaum, D. G., 1986. Social ties and mortality in Evans County, Georgia. American Journal of Epidemiology 123, 577-591.

Smith, J. P., 1999. Healthy bodies and thick wallets: The dual relation between health and economic status. Journal of Economic Perspectives 13(2), 145-166.

Taylor, M. F., Brice, J., Buck, N., Prentice-Lane, E., 2002. British Household Panel Survey User Manual. University of Essex, Colchester.

Thatcher, A. R., 1999. The long-term pattern of adult mortality and the highest attained age. Journal of the Royal Statistical Society (Series A) 162(1), 5-43.

Wilkinson, R. G., 1996. Unhealthy Societies: The Afflictions of Inequality. Routledge, London.

Wilson, C. M., Oswald, A. J., 2002. How does marriage affect physical and psychological health? A survey of the longitudinal evidence. Mimeo. Department of Economics, University of Warwick.

Whooley, M. A., Browner, W. S., 1998. Association between depressive symptoms and mortality in older women. Archives of Internal Medicine 58(19), 2129-35.

Wolfson, M., Rowe, G., Gentleman, J. F., Tomiak, M., 1993. Career Earnings and Death: A Longitudinal Analysis of Older Canadian Men. Journal of Gerontology 48(4), 167-179. 
TABLE 1a

Male Mortality Equations

Dependent Variable: Deceased between 1992 and 2001

\begin{tabular}{|c|c|c|c|c|c|c|}
\hline Regressors (1991) & $\begin{array}{c}\text { Males } \\
I \\
\end{array}$ & $\begin{array}{c}\text { Males } \\
\text { II }\end{array}$ & $\begin{array}{c}\text { Males } \\
\text { III }\end{array}$ & $\begin{array}{c}\text { Males } \\
\text { IV }\end{array}$ & $\begin{array}{c}\text { Males } \\
V\end{array}$ & $\begin{array}{c}\text { Males } \\
\text { VI }\end{array}$ \\
\hline $1^{\text {st }}$ Income quintile (Lowest) & $\begin{array}{r}0.085 \\
(0.039)\end{array}$ & & & $\begin{array}{r}0.046 \\
(0.036)\end{array}$ & & \\
\hline $2^{\text {nd }}$ Income quintile & $\begin{array}{r}0.045 \\
(0.033)\end{array}$ & & & $\begin{array}{r}0.014 \\
(0.031)\end{array}$ & & \\
\hline $3^{\text {rd }}$ Income quintile & $\begin{array}{r}0.021 \\
(0.025)\end{array}$ & & & $\begin{array}{r}0.007 \\
(0.024)\end{array}$ & & \\
\hline $4^{\text {th }}$ Income quintile & $\begin{array}{r}0.006 \\
(0.020)\end{array}$ & & & $\begin{array}{r}0.000 \\
(0.019)\end{array}$ & & \\
\hline Ln(Household Income p.h.) & & $\begin{array}{r}-0.045 \\
(0.018)\end{array}$ & $\begin{array}{r}-0.030 \\
(0.018)\end{array}$ & & $\begin{array}{r}-0.025 \\
(0.018)\end{array}$ & $\begin{array}{c}-0.014 \\
(0.018)\end{array}$ \\
\hline Years Unemployed & & & $\begin{array}{r}0.014 \\
(0.004)\end{array}$ & & & $\begin{array}{r}0.013 \\
(0.004)\end{array}$ \\
\hline Years Out of the Labour Force & & & $\begin{array}{r}0.002 \\
(0.001)\end{array}$ & & & $\begin{array}{r}0.001 \\
(0.001)\end{array}$ \\
\hline Married & $\begin{array}{r}-0.072 \\
(0.025)\end{array}$ & $\begin{array}{r}-0.101 \\
(0.024)\end{array}$ & $\begin{array}{r}-0.082 \\
(0.023)\end{array}$ & $\begin{array}{r}-0.063 \\
(0.024)\end{array}$ & $\begin{array}{r}-0.081 \\
(0.023)\end{array}$ & $\begin{array}{r}-0.067 \\
(0.023)\end{array}$ \\
\hline Age & $\begin{array}{r}0.012 \\
(0.001)\end{array}$ & $\begin{array}{r}0.013 \\
(0.001)\end{array}$ & $\begin{array}{r}0.011 \\
(0.001)\end{array}$ & $\begin{array}{r}0.013 \\
(0.001)\end{array}$ & $\begin{array}{r}0.013 \\
(0.001)\end{array}$ & $\begin{array}{r}0.012 \\
(0.001)\end{array}$ \\
\hline Education: Intermediate & $\begin{array}{r}-0.021 \\
(0.022)\end{array}$ & $\begin{array}{r}-0.018 \\
(0.022)\end{array}$ & $\begin{array}{r}-0.015 \\
(0.022)\end{array}$ & $\begin{array}{r}-0.008 \\
(0.022)\end{array}$ & $\begin{array}{r}-0.006 \\
(0.022)\end{array}$ & $\begin{array}{r}-0.003 \\
(0.022)\end{array}$ \\
\hline Education: Degree & $\begin{array}{r}-0.056 \\
(0.030)\end{array}$ & $\begin{array}{r}-0.051 \\
(0.031)\end{array}$ & $\begin{array}{r}-0.044 \\
(0.031)\end{array}$ & $\begin{array}{r}-0.024 \\
(0.032)\end{array}$ & $\begin{array}{r}-0.020 \\
(0.033)\end{array}$ & $\begin{array}{c}-0.014 \\
(0.033)\end{array}$ \\
\hline Smoker & & & & $\begin{array}{r}0.050 \\
(0.020)\end{array}$ & $\begin{array}{r}0.050 \\
(0.020)\end{array}$ & $\begin{array}{r}0.042 \\
(0.020)\end{array}$ \\
\hline Health: Excellent & & & & $\begin{array}{r}-0.032 \\
(0.018)\end{array}$ & $\begin{array}{r}-0.032 \\
(0.018)\end{array}$ & $\begin{array}{r}-0.034 \\
(0.018)\end{array}$ \\
\hline Health: Fair & & & & $\begin{array}{r}0.087 \\
(0.026)\end{array}$ & $\begin{array}{r}0.086 \\
(0.025)\end{array}$ & $\begin{array}{r}0.084 \\
(0.025)\end{array}$ \\
\hline Health: Poor & & & & $\begin{array}{r}0.185 \\
(0.036)\end{array}$ & $\begin{array}{r}0.185 \\
(0.035)\end{array}$ & $\begin{array}{r}0.178 \\
(0.036)\end{array}$ \\
\hline Observations & 1646 & 1646 & 1626 & 1646 & 1646 & 1626 \\
\hline Log-L & -641.3 & -641.8 & -625.1 & -609.2 & -609.6 & -596.0 \\
\hline Pseudo $\mathrm{R}^{2}$ & 0.254 & 0.253 & 0.263 & 0.291 & 0.291 & 0.297 \\
\hline
\end{tabular}

1. The independent variables are measured at the start of the period, ie. in 1991.

2. All columns are estimated by the Logit Maximum Likelihood technique. (Average) Marginal effects are reported. Positive coefficients denote a greater probability of mortality in the period.

3. Standard errors (calculated by the delta method) are in parentheses.

4. The base individual is single with no academic qualification, and in columns four to six is also a non-smoker with good health status.

5. Household income is averaged for the years 1991 and 1992. Household income per head is calculated as mean income per household per adult equivalent (the number of adults plus $1 / 2$ the number of children aged less than 18).

6. The Pseudo $\mathrm{R}^{2}$ is calculated using the method of McFadden (1974).

7. The marginal effect on the years unemployed and years out of the labour force are relative to the (omitted) years employed. 
TABLE 1b

Female Mortality Equations (BHPS)

Dependent Variable: Deceased between 1992 and 2001

\begin{tabular}{|c|c|c|c|c|c|c|}
\hline \multirow{2}{*}{ Regressors (1991) } & \multicolumn{6}{|c|}{ Females Females Females Females Females Females } \\
\hline & $I$ & II & III & IV & $V$ & $V I$ \\
\hline \multirow[t]{2}{*}{$1^{\text {st }}$ Income quintile (Lowest) } & 0.006 & & & -0.009 & & \\
\hline & (0.037) & & & $(0.036)$ & & \\
\hline \multirow{2}{*}{$2^{\text {nd }}$ Income quintile } & -0.013 & & & -0.024 & & \\
\hline & $(0.025)$ & & & $(0.025)$ & & \\
\hline \multirow[t]{2}{*}{$3^{\text {rd }}$ Income quintile } & -0.003 & & & -0.011 & & \\
\hline & $(0.020)$ & & & $(0.020)$ & & \\
\hline \multirow[t]{2}{*}{$4^{\text {th }}$ Income quintile } & -0.008 & & & -0.009 & & \\
\hline & $(0.015)$ & & & $(0.015)$ & & \\
\hline \multirow[t]{2}{*}{ Ln(Household Income p.h.) } & & -0.012 & -0.017 & & 0.001 & -0.004 \\
\hline & & $(0.016)$ & $(0.016)$ & & $(0.016)$ & $(0.016)$ \\
\hline \multirow[t]{2}{*}{ Years Unemployed } & & & -0.004 & & & -0.005 \\
\hline & & & $(0.004)$ & & & $(0.004)$ \\
\hline \multirow[t]{2}{*}{ Years Out of the Labour Force } & & & 0.000 & & & 0.000 \\
\hline & & & $(0.000)$ & & & $(0.000)$ \\
\hline \multirow[t]{2}{*}{ Married } & -0.041 & -0.047 & -0.045 & -0.034 & -0.039 & -0.037 \\
\hline & $(0.019)$ & $(0.017)$ & $(0.017)$ & $(0.018)$ & $(0.016)$ & $(0.016)$ \\
\hline \multirow[t]{2}{*}{ Age } & 0.012 & 0.012 & 0.012 & 0.013 & 0.013 & 0.012 \\
\hline & $(0.001)$ & $(0.001)$ & $(0.001)$ & $(0.001)$ & $(0.001)$ & $(0.001)$ \\
\hline \multirow[t]{2}{*}{ Education: Intermediate } & -0.029 & -0.027 & -0.023 & -0.006 & -0.006 & -0.002 \\
\hline & $(0.020)$ & $(0.020)$ & $(0.020)$ & $(0.021)$ & $(0.021)$ & $(0.021)$ \\
\hline \multirow[t]{2}{*}{ Education: Degree } & -0.033 & -0.027 & -0.021 & -0.010 & -0.010 & -0.005 \\
\hline & $(0.032)$ & $(0.033)$ & $(0.033)$ & $(0.033)$ & $(0.034)$ & $(0.034)$ \\
\hline \multirow[t]{2}{*}{ Smoker } & & & & 0.052 & 0.052 & 0.052 \\
\hline & & & & $(0.018)$ & $(0.018)$ & $(0.018)$ \\
\hline \multirow[t]{2}{*}{ Health: Excellent } & & & & -0.043 & -0.043 & -0.041 \\
\hline & & & & $(0.016)$ & $(0.016)$ & $(0.016)$ \\
\hline \multirow[t]{2}{*}{ Health: Fair } & & & & 0.004 & 0.004 & 0.006 \\
\hline & & & & (0.019) & (0.019) & (0.019) \\
\hline \multirow[t]{2}{*}{ Health: Poor } & & & & 0.130 & 0.129 & 0.131 \\
\hline & & & & $(0.028)$ & $(0.028)$ & $(0.028)$ \\
\hline Observations & 2049 & 2049 & 2021 & 2049 & 2049 & 2021 \\
\hline Log-L & -700.8 & -701.1 & -686.1 & -675.0 & -675.7 & -661.0 \\
\hline Pseudo $\mathrm{R}^{2}$ & 0.292 & 0.292 & 0.291 & 0.318 & 0.317 & 0.317 \\
\hline
\end{tabular}


TABLE 2a

Male Mortality and Marital Status

Dependent Variable: Deceased between 1992 and 2001

\begin{tabular}{|c|c|c|c|c|c|c|}
\hline Regressors (1991) & $\begin{array}{c}\text { Males } \\
I\end{array}$ & $\begin{array}{c}\text { Males } \\
\text { II }\end{array}$ & $\begin{array}{c}\text { Males } \\
\text { III }\end{array}$ & $\begin{array}{c}\text { Males } \\
\text { IV }\end{array}$ & $\begin{array}{c}\text { Males } \\
V\end{array}$ & $\begin{array}{c}\text { Males } \\
\text { VI }\end{array}$ \\
\hline Ln(Household Income p.h.) & $\begin{array}{r}-0.049 \\
(0.018)\end{array}$ & $\begin{array}{r}-0.049 \\
(0.018)\end{array}$ & $\begin{array}{r}-0.049 \\
(0.018)\end{array}$ & $\begin{array}{l}-0.049 \\
(0.018)\end{array}$ & $\begin{array}{r}-0.049 \\
(0.018)\end{array}$ & $\begin{array}{l}-0.049 \\
(0.018)\end{array}$ \\
\hline Married & $\begin{array}{r}-0.097 \\
(0.024)\end{array}$ & $\begin{array}{r}-0.096 \\
(0.024)\end{array}$ & $\begin{array}{r}-0.096 \\
(0.024)\end{array}$ & $\begin{array}{l}-0.096 \\
(0.024)\end{array}$ & $\begin{array}{r}-0.094 \\
(0.024)\end{array}$ & $\begin{array}{r}-0.096 \\
(0.024)\end{array}$ \\
\hline High stress & & $\begin{array}{r}0.013 \\
(0.024)\end{array}$ & & & & \\
\hline Not playing a useful role & & & $\begin{array}{r}0.003 \\
(0.024)\end{array}$ & & & \\
\hline Constantly under strain & & & & $\begin{array}{r}0.010 \\
(0.023)\end{array}$ & & \\
\hline Unhappy or depressed & & & & & $\begin{array}{r}0.033 \\
(0.026)\end{array}$ & \\
\hline Low belief in self-worth & & & & & & $\begin{array}{r}0.014 \\
(0.041)\end{array}$ \\
\hline Age & $\begin{array}{r}0.012 \\
(0.001)\end{array}$ & $\begin{array}{r}0.012 \\
(0.001)\end{array}$ & $\begin{array}{r}0.012 \\
(0.001)\end{array}$ & $\begin{array}{r}0.012 \\
(0.001)\end{array}$ & $\begin{array}{r}0.012 \\
(0.001)\end{array}$ & $\begin{array}{r}0.012 \\
(0.001)\end{array}$ \\
\hline Education: Intermediate & $\begin{array}{r}-0.017 \\
(0.022)\end{array}$ & $\begin{array}{r}-0.016 \\
(0.022)\end{array}$ & $\begin{array}{r}-0.017 \\
(0.022)\end{array}$ & $\begin{array}{r}-0.017 \\
(0.022)\end{array}$ & $\begin{array}{r}-0.017 \\
(0.022)\end{array}$ & $\begin{array}{r}-0.017 \\
(0.022)\end{array}$ \\
\hline Education: Degree & $\begin{array}{r}-0.047 \\
(0.032)\end{array}$ & $\begin{array}{r}-0.046 \\
(0.032)\end{array}$ & $\begin{array}{r}-0.047 \\
(0.032)\end{array}$ & $\begin{array}{l}-0.047 \\
(0.032)\end{array}$ & $\begin{array}{l}-0.046 \\
(0.032)\end{array}$ & $\begin{array}{r}-0.047 \\
(0.032)\end{array}$ \\
\hline Observations & 1605 & 1605 & 1605 & 1605 & 1605 & 1605 \\
\hline $\begin{array}{l}\text { Log-L } \\
\text { P }\end{array}$ & -623.4 & -623.3 & -623.4 & -623.3 & -622.6 & -623.4 \\
\hline Pseudo $\mathrm{R}^{2}$ & 0.248 & 0.248 & 0.248 & 0.248 & 0.249 & 0.248 \\
\hline
\end{tabular}

1. See notes Table $1 \mathrm{a}$.

2. High stress denotes an individual who responds to 4 or more of the 12 GHQ questions negatively (see Bowling, 1997). Playing a useful role, Constantly under strain, Unhappy or depressed, and Believe in self-worth are all variables coded 1 if the individual answers negatively. 
TABLE 2b

Female Mortality and Marital Status

Dependent Variable: Deceased between 1992 and 2001

\begin{tabular}{|c|c|c|c|c|c|c|}
\hline \multirow{2}{*}{ Regressors (1991) } & Females & Females & Females & Females & Females & Females \\
\hline & $I$ & II & III & $I V$ & V & $V I$ \\
\hline \multirow[t]{2}{*}{ Ln(Household Income p.h.) } & -0.009 & -0.004 & -0.002 & -0.007 & -0.006 & -0.006 \\
\hline & $(0.016)$ & $(0.016)$ & $(0.016)$ & $(0.016)$ & $(0.016)$ & $(0.016)$ \\
\hline \multirow[t]{2}{*}{ Married } & -0.053 & -0.049 & -0.046 & -0.053 & -0.051 & -0.050 \\
\hline & $(0.017)$ & (0.017) & $(0.017)$ & $(0.017)$ & (0.017) & (0.017) \\
\hline \multirow[t]{2}{*}{ High stress } & & 0.066 & & & & \\
\hline & & $(0.020)$ & & & & \\
\hline Not playing a useful role & & & $\begin{array}{r}0.103 \\
(0.023)\end{array}$ & & & \\
\hline Constantly under strain & & & & $\begin{array}{r}0.025 \\
(0.018)\end{array}$ & & \\
\hline Unhappy or depressed & & & & & $\begin{array}{r}0.040 \\
(0.020)\end{array}$ & \\
\hline Low belief in self-worth & & & & & & $\begin{array}{r}0.109 \\
(0.035)\end{array}$ \\
\hline \multirow[t]{2}{*}{ Age } & 0.012 & 0.012 & 0.012 & 0.012 & 0.012 & 0.012 \\
\hline & $(0.001)$ & $(0.001)$ & $(0.001)$ & $(0.001)$ & $(0.001)$ & $(0.001)$ \\
\hline \multirow[t]{2}{*}{ Education: Intermediate } & -0.023 & -0.020 & -0.021 & -0.022 & -0.021 & -0.021 \\
\hline & $(0.020)$ & $(0.020)$ & $(0.020)$ & $(0.020)$ & $(0.020)$ & $(0.020)$ \\
\hline \multirow[t]{2}{*}{ Education: Degree } & -0.021 & -0.018 & -0.016 & -0.022 & -0.019 & -0.020 \\
\hline & (0.033) & $(0.032)$ & $(0.033)$ & $(0.032)$ & $(0.033)$ & $(0.033)$ \\
\hline Observations & 1976 & 1976 & 1976 & 1976 & 1976 & 1976 \\
\hline Log-L & -664.0 & -658.0 & -651.5 & -663.0 & -661.7 & -658.4 \\
\hline Pseudo $\mathrm{R}^{2}$ & 0.288 & 0.294 & 0.301 & 0.289 & 0.290 & 0.294 \\
\hline
\end{tabular}

1. See notes Table 1a.

2. High stress denotes an individual who responds to 4 or more of the 12 GHQ questions negatively (see Bowling, 1997). Playing a useful role, Constantly under strain, Unhappy or depressed, and Believe in self-worth are all variables coded 1 if the individual answers negatively. 
TABLE 3a

Male Mortality and Marital Status

Dependent Variable: Deceased between 1992 and 2001

\begin{tabular}{|c|c|c|c|c|c|c|}
\hline Regressors (1991) & $\begin{array}{c}\text { Males } \\
I \\
\end{array}$ & $\begin{array}{c}\text { Males } \\
\text { II }\end{array}$ & $\begin{array}{c}\text { Males } \\
\text { III }\end{array}$ & $\begin{array}{c}\text { Males } \\
\text { IV }\end{array}$ & $\begin{array}{c}\text { Males } \\
V\end{array}$ & $\begin{array}{c}\text { Males } \\
\text { VII }\end{array}$ \\
\hline Ln(Household Income p.h.) & $\begin{array}{r}-0.032 \\
(0.018)\end{array}$ & $\begin{array}{r}-0.033 \\
(0.018)\end{array}$ & $\begin{array}{r}-0.032 \\
(0.018)\end{array}$ & $\begin{array}{r}-0.037 \\
(0.018)\end{array}$ & $\begin{array}{r}-0.038 \\
(0.018)\end{array}$ & $\begin{array}{r}-0.037 \\
(0.018)\end{array}$ \\
\hline Married & $\begin{array}{r}-0.078 \\
(0.023)\end{array}$ & $\begin{array}{r}-0.079 \\
(0.023)\end{array}$ & $\begin{array}{r}-0.078 \\
(0.023)\end{array}$ & $\begin{array}{r}-0.088 \\
(0.023)\end{array}$ & $\begin{array}{r}-0.089 \\
(0.023)\end{array}$ & $\begin{array}{l}-0.088 \\
(0.023)\end{array}$ \\
\hline High stress & $\begin{array}{r}-0.044 \\
(0.023)\end{array}$ & & & $\begin{array}{r}-0.024 \\
(0.023)\end{array}$ & & \\
\hline Not playing a useful role & & $\begin{array}{r}-0.049 \\
(0.022)\end{array}$ & & & $\begin{array}{r}-0.030 \\
(0.023)\end{array}$ & \\
\hline Low belief in self-worth & & & $\begin{array}{r}-0.052 \\
(0.035)\end{array}$ & & & $\begin{array}{r}-0.026 \\
(0.038)\end{array}$ \\
\hline Age & $\begin{array}{r}0.013 \\
(0.001)\end{array}$ & $\begin{array}{r}0.013 \\
(0.001)\end{array}$ & $\begin{array}{r}0.013 \\
(0.001)\end{array}$ & $\begin{array}{r}0.012 \\
(0.001)\end{array}$ & $\begin{array}{r}0.012 \\
(0.001)\end{array}$ & $\begin{array}{r}0.012 \\
(0.001)\end{array}$ \\
\hline Education: Intermediate & $\begin{array}{l}-0.007 \\
(0.022)\end{array}$ & $\begin{array}{r}-0.006 \\
(0.022)\end{array}$ & $\begin{array}{r}-0.007 \\
(0.022)\end{array}$ & $\begin{array}{r}-0.009 \\
(0.022)\end{array}$ & $\begin{array}{r}-0.008 \\
(0.022)\end{array}$ & $\begin{array}{r}-0.009 \\
(0.022)\end{array}$ \\
\hline Education: Degree & $\begin{array}{l}-0.018 \\
(0.033)\end{array}$ & $\begin{array}{r}-0.016 \\
(0.033)\end{array}$ & $\begin{array}{r}-0.018 \\
(0.033)\end{array}$ & $\begin{array}{r}-0.033 \\
(0.033)\end{array}$ & $\begin{array}{r}-0.032 \\
(0.033)\end{array}$ & $\begin{array}{l}-0.032 \\
(0.033)\end{array}$ \\
\hline Smoker & $\begin{array}{r}0.048 \\
(0.021)\end{array}$ & $\begin{array}{r}0.048 \\
(0.021)\end{array}$ & $\begin{array}{r}0.047 \\
(0.021)\end{array}$ & $\begin{array}{r}0.059 \\
(0.021)\end{array}$ & $\begin{array}{r}0.059 \\
(0.021)\end{array}$ & $\begin{array}{r}0.058 \\
(0.021)\end{array}$ \\
\hline Health: Excellent & $\begin{array}{l}-0.040 \\
(0.018)\end{array}$ & $\begin{array}{r}-0.039 \\
(0.018)\end{array}$ & $\begin{array}{r}-0.038 \\
(0.018)\end{array}$ & & & \\
\hline Health: Fair & $\begin{array}{r}0.082 \\
(0.026)\end{array}$ & $\begin{array}{r}0.082 \\
(0.026)\end{array}$ & $\begin{array}{r}0.079 \\
(0.026)\end{array}$ & & & \\
\hline Health: Poor & $\begin{array}{r}0.197 \\
(0.038)\end{array}$ & $\begin{array}{r}0.200 \\
(0.038)\end{array}$ & $\begin{array}{r}0.190 \\
(0.037)\end{array}$ & & & \\
\hline Health problems: 1 & & & & $\begin{array}{r}0.051 \\
(0.020)\end{array}$ & $\begin{array}{r}0.051 \\
(0.020)\end{array}$ & $\begin{array}{r}0.051 \\
(0.020)\end{array}$ \\
\hline Health problems: 2 & & & & $\begin{array}{r}0.077 \\
(0.025)\end{array}$ & $\begin{array}{r}0.078 \\
(0.025)\end{array}$ & $\begin{array}{r}0.077 \\
(0.025)\end{array}$ \\
\hline Health problems: 3 & & & & $\begin{array}{r}0.106 \\
(0.035)\end{array}$ & $\begin{array}{r}0.108 \\
(0.036)\end{array}$ & $\begin{array}{r}0.103 \\
(0.035)\end{array}$ \\
\hline Health problems: 4 or more & & & & $\begin{array}{r}0.183 \\
(0.047)\end{array}$ & $\begin{array}{r}0.184 \\
(0.047)\end{array}$ & $\begin{array}{r}0.177 \\
(0.045)\end{array}$ \\
\hline $\begin{array}{l}\text { Observations } \\
\text { Log-L } \\
\text { Pseudo } \mathrm{R}^{2}\end{array}$ & $\begin{array}{r}1605 \\
-591.4 \\
0.286 \\
\end{array}$ & $\begin{array}{r}1605 \\
-591.0 \\
0.287 \\
\end{array}$ & $\begin{array}{r}1605 \\
-592.3 \\
0.285 \\
\end{array}$ & $\begin{array}{r}1605 \\
-604.0 \\
0.271 \\
\end{array}$ & $\begin{array}{r}1605 \\
-603.7 \\
0.272 \\
\end{array}$ & $\begin{array}{r}1605 \\
-604.3 \\
0.271 \\
\end{array}$ \\
\hline
\end{tabular}

1. See notes Table 1a.

2. High stress denotes an individual who responds to 4 or more of the 12 GHQ questions negatively (see Bowling, 1997). Playing a useful role, Constantly under strain, Unhappy or depressed, and Believe in self-worth are all variables coded 1 if the individual answers negatively. 'Health problems' are relative to the omitted base of no reported health problems. 
TABLE 3b

Female Mortality and Marital Status

Dependent Variable: Deceased between 1992 and 2001

\begin{tabular}{|c|c|c|c|c|c|c|}
\hline & Females & Females & Females & Females & Females & Females \\
\hline Regressors (1991) & $I$ & II & III & $I V$ & V & $V I$ \\
\hline Ln(Household Income p.h.) & 0.005 & 0.007 & 0.005 & 0.001 & 0.003 & 0.000 \\
\hline & $(0.016)$ & $(0.016)$ & $(0.016)$ & $(0.016)$ & $(0.016)$ & $(0.016)$ \\
\hline Married & -0.046 & -0.043 & -0.045 & -0.044 & -0.041 & -0.044 \\
\hline & $(0.017)$ & (0.017) & $(0.017)$ & $(0.017)$ & $(0.017)$ & (0.017) \\
\hline High stress & 0.027 & & & 0.046 & & \\
\hline & $(0.020)$ & & & $(0.020)$ & & \\
\hline Not playing a useful role & & 0.072 & & & 0.088 & \\
\hline & & $(0.022)$ & & & $(0.022)$ & \\
\hline Low belief in self-worth & & & 0.066 & & & 0.088 \\
\hline & & & $(0.033)$ & & & $(0.034)$ \\
\hline Age & 0.012 & 0.012 & 0.012 & 0.012 & 0.012 & 0.012 \\
\hline & $(0.001)$ & $(0.001)$ & $(0.001)$ & $(0.001)$ & $(0.001)$ & $(0.001)$ \\
\hline Education: Intermediate & -0.005 & -0.006 & -0.004 & -0.014 & -0.015 & -0.014 \\
\hline & $(0.021)$ & $(0.020)$ & $(0.021)$ & $(0.020)$ & $(0.020)$ & $(0.020)$ \\
\hline Education: Degree & -0.006 & -0.005 & -0.007 & -0.007 & -0.006 & -0.008 \\
\hline & $(0.033)$ & $(0.034)$ & $(0.034)$ & $(0.034)$ & $(0.034)$ & $(0.034)$ \\
\hline Smoker & 0.050 & 0.050 & 0.051 & 0.051 & 0.051 & 0.054 \\
\hline & (0.018) & (0.018) & $(0.018)$ & $(0.018)$ & $(0.018)$ & $(0.018)$ \\
\hline Health: Excellent & -0.043 & -0.043 & -0.043 & & & \\
\hline & $(0.016)$ & $(0.016)$ & $(0.016)$ & & & \\
\hline Health: Fair & -0.010 & -0.014 & -0.008 & & & \\
\hline & (0.019) & (0.019) & $(0.019)$ & & & \\
\hline Health: Poor & 0.109 & 0.095 & 0.111 & & & \\
\hline & $(0.030)$ & $(0.029)$ & $(0.029)$ & & & \\
\hline Health problems: 1 & & & & 0.004 & 0.002 & 0.004 \\
\hline & & & & $(0.016)$ & $(0.016)$ & $(0.016)$ \\
\hline Health problems: 2 & & & & 0.034 & 0.031 & 0.035 \\
\hline & & & & $(0.020)$ & $(0.020)$ & $(0.020)$ \\
\hline Health problems: 3 & & & & 0.028 & 0.025 & 0.033 \\
\hline & & & & $(0.023)$ & $(0.023)$ & $(0.023)$ \\
\hline Health problems: 4 or more & & & & 0.064 & 0.056 & 0.068 \\
\hline & & & & $(0.031)$ & $(0.030)$ & $(0.031)$ \\
\hline Observations & 1976 & 1976 & 1976 & 1976 & 1976 & 1976 \\
\hline Log-L & -639.4 & -634.4 & -638.1 & -650.1 & -643.9 & -649.1 \\
\hline Pseudo $\mathrm{R}^{2}$ & 0.314 & 0.319 & 0.315 & 0.302 & 0.309 & 0.303 \\
\hline
\end{tabular}

1. See notes Table 1a.

2. High stress denotes an individual who responds to 4 or more of the 12 GHQ questions negatively (see Bowling, 1997). Playing a useful role, Constantly under strain, Unhappy or depressed, and Believe in self-worth are all variables coded 1 if the individual answers negatively. 'Health problems' are relative to the omitted base of no reported health problems. 


\section{TABLE 4a}

Male Mortality and Marital Status

Dependent Variable: Deceased between 1992 and 2001

\begin{tabular}{|c|c|c|c|c|c|c|c|c|c|}
\hline Regressors (1991) & $\begin{array}{c}\text { All } \\
I\end{array}$ & $\begin{array}{c}\text { Males } \\
\text { No } \\
\text { Education } \\
\text { II }\end{array}$ & $\begin{array}{c}\text { Males } \\
\text { O-level } \\
\text { or above } \\
\text { III }\end{array}$ & $\begin{array}{l}\text { Smoker } \\
\text { IV }\end{array}$ & $\begin{array}{c}\text { Non-smoker } \\
V\end{array}$ & $\begin{array}{l}\text { Married } \\
\text { VI }\end{array}$ & $\begin{array}{c}\text { Males } \\
\text { Not } \\
\text { married } \\
\text { VII }\end{array}$ & $\begin{array}{c}\text { Males } \\
\text { Below } \\
\text { Median } \\
\text { Income } \\
\text { VIII }\end{array}$ & $\begin{array}{c}\text { Males } \\
\text { Above } \\
\text { Median } \\
\text { Income } \\
\text { VI }\end{array}$ \\
\hline Ln(Household Income p.h.) & $\begin{array}{l}-0.038 \\
(0.018)\end{array}$ & $\begin{array}{r}-0.062 \\
(0.028)\end{array}$ & $\begin{array}{r}-0.012 \\
(0.022)\end{array}$ & $\begin{array}{r}-0.060 \\
(0.036)\end{array}$ & $\begin{aligned}-0.028 \\
(0.021)\end{aligned}$ & $\begin{array}{r}-0.025 \\
(0.020)\end{array}$ & $\begin{array}{r}-0.080 \\
(0.047)\end{array}$ & $\begin{aligned}-0.063 \\
(0.042)\end{aligned}$ & $\begin{array}{r}-0.015 \\
(0.024)\end{array}$ \\
\hline Married & $\begin{array}{l}-0.089 \\
(0.023)\end{array}$ & $\begin{array}{r}-0.140 \\
(0.033)\end{array}$ & $\begin{array}{r}-0.015 \\
(0.031)\end{array}$ & $\begin{array}{r}-0.109 \\
(0.044)\end{array}$ & $\begin{array}{r}-0.073 \\
(0.028)\end{array}$ & & & $\begin{array}{l}-0.127 \\
(0.036)\end{array}$ & $\begin{array}{r}-0.042 \\
(0.035)\end{array}$ \\
\hline Not playing a useful role & $\begin{array}{r}-0.030 \\
(0.023)\end{array}$ & $\begin{array}{r}-0.025 \\
(0.033)\end{array}$ & $\begin{array}{r}-0.035 \\
(0.029)\end{array}$ & $\begin{array}{r}-0.009 \\
(0.043)\end{array}$ & $\begin{array}{r}-0.048 \\
(0.026)\end{array}$ & $\begin{array}{r}-0.025 \\
(0.025)\end{array}$ & $\begin{array}{r}-0.048 \\
(0.057)\end{array}$ & $\begin{array}{r}-0.056 \\
(0.039)\end{array}$ & $\begin{array}{r}-0.012 \\
(0.026)\end{array}$ \\
\hline $\begin{array}{l}\text { Other control variables } \\
\text { (as in Table } 4 \mathrm{a} \text { - columns } 4 \text { to } 6 \text { ) }\end{array}$ & & & & & & & & & \\
\hline $\begin{array}{l}\text { Observations } \\
\text { Log-L } \\
\text { Pseudo } \mathrm{R}^{2}\end{array}$ & $\begin{array}{r}1605 \\
-603.7 \\
0.272 \\
\end{array}$ & $\begin{array}{r}884 \\
-391.8 \\
0.252 \\
\end{array}$ & $\begin{array}{r}721 \\
-206.5 \\
0.255 \\
\end{array}$ & $\begin{array}{r}437 \\
-181.1 \\
0.237\end{array}$ & $\begin{array}{r}1168 \\
-418.9 \\
0.291 \\
\end{array}$ & $\begin{array}{r}1278 \\
-444.6 \\
0.249 \\
\end{array}$ & $\begin{array}{r}327 \\
-152.6 \\
0.284\end{array}$ & $\begin{array}{r}730 \\
-368.9 \\
0.217 \\
\end{array}$ & $\begin{array}{r}875 \\
-229.0 \\
0.192 \\
\end{array}$ \\
\hline
\end{tabular}

1. See notes Table 1a.

2. Where applicable, all columns include controls for age, education, whether a smoker and number of health problems. 


\section{TABLE 4b}

Female Mortality and Marital Status

Dependent Variable: Deceased between 1992 and 2001

\begin{tabular}{|c|c|c|c|c|c|c|c|c|c|}
\hline Regressors (1991) & Females & $\begin{array}{c}\text { Females } \\
\\
\text { No } \\
\text { Education } \\
\text { II }\end{array}$ & $\begin{array}{c}\text { Females } \\
\text { O-level } \\
\text { or above } \\
\text { III }\end{array}$ & $\begin{array}{c}\text { Smoker } \\
\text { IV }\end{array}$ & $\begin{array}{c}\text { Non-smoker } \\
V\end{array}$ & $\begin{array}{c}\text { Married } \\
\text { VI }\end{array}$ & $\begin{array}{c}\text { Females } \\
\text { Not } \\
\text { married } \\
\text { VII }\end{array}$ & $\begin{array}{c}\text { Females } \\
\text { Below } \\
\text { Median } \\
\text { Income } \\
\text { VIII }\end{array}$ & $\begin{array}{c}\text { Females } \\
\text { Above } \\
\text { Median } \\
\text { Income } \\
\text { VI }\end{array}$ \\
\hline Ln(Household Income p.h.) & $\begin{array}{r}0.003 \\
(0.016)\end{array}$ & $\begin{array}{r}-0.008 \\
(0.023)\end{array}$ & $\begin{array}{r}0.018 \\
(0.019)\end{array}$ & $\begin{array}{l}-0.026 \\
(0.029)\end{array}$ & $\begin{array}{r}0.013 \\
(0.019)\end{array}$ & $\begin{array}{r}0.001 \\
(0.016)\end{array}$ & $\begin{array}{r}0.005 \\
(0.037)\end{array}$ & $\begin{array}{r}-0.034 \\
(0.036)\end{array}$ & $\begin{array}{r}0.034 \\
(0.017)\end{array}$ \\
\hline Married & $\begin{array}{l}-0.041 \\
(0.017)\end{array}$ & $\begin{array}{r}-0.039 \\
(0.023)\end{array}$ & $\begin{array}{r}-0.042 \\
(0.022)\end{array}$ & $\begin{array}{r}-0.020 \\
(0.030)\end{array}$ & $\begin{array}{l}-0.052 \\
(0.020)\end{array}$ & & & $\begin{array}{r}-0.047 \\
(0.027)\end{array}$ & $\begin{array}{l}-0.036 \\
(0.022)\end{array}$ \\
\hline Not playing a useful role & $\begin{array}{r}0.088 \\
(0.022)\end{array}$ & $\begin{array}{r}0.083 \\
(0.028)\end{array}$ & $\begin{array}{r}0.105 \\
(0.041)\end{array}$ & $\begin{array}{r}0.120 \\
(0.042)\end{array}$ & $\begin{array}{r}0.076 \\
(0.026)\end{array}$ & $\begin{array}{r}0.077 \\
(0.030)\end{array}$ & $\begin{array}{r}0.119 \\
(0.038)\end{array}$ & $\begin{array}{r}0.132 \\
(0.033)\end{array}$ & $\begin{array}{r}0.035 \\
(0.030)\end{array}$ \\
\hline $\begin{array}{l}\text { Other control varia } \\
\text { (as in Table } 4 b-c c\end{array}$ & & & & & & & & & \\
\hline $\begin{array}{l}\text { Observations } \\
\text { Log-L } \\
\text { Pseudo } \mathrm{R}^{2}\end{array}$ & $\begin{array}{r}1976 \\
-643.9 \\
0.309\end{array}$ & $\begin{array}{r}1272 \\
-489.5 \\
0.283\end{array}$ & $\begin{array}{r}704 \\
-151.0 \\
0.311\end{array}$ & $\begin{array}{r}512 \\
-157.9 \\
0.328\end{array}$ & $\begin{array}{r}1464 \\
-480.9 \\
0.310\end{array}$ & $\begin{array}{r}1252 \\
-314.8 \\
0.199\end{array}$ & $\begin{array}{r}724 \\
-325.4 \\
0.289\end{array}$ & $\begin{array}{r}1042 \\
-473.2 \\
0.242\end{array}$ & $\begin{array}{r}934 \\
-164.5 \\
0.234\end{array}$ \\
\hline
\end{tabular}

1. See notes Table 1 a

2. Where applicable, all columns include controls for age, education, whether a smoker and number of health problems. 
TABLE 5a

Male Mortality and Marital Status

Those aged 40 to 65

Dependent Variable: Deceased between 1992 and 2001

\begin{tabular}{|c|c|c|c|c|c|c|}
\hline Regressors (1991) & $\begin{array}{c}\text { Males } \\
\text { I }\end{array}$ & $\begin{array}{c}\text { Males } \\
\text { II }\end{array}$ & $\begin{array}{c}\text { Males } \\
\text { III }\end{array}$ & $\begin{array}{c}\text { Males } \\
\text { IV }\end{array}$ & $\begin{array}{c}\text { Males } \\
\text { V }\end{array}$ & $\begin{array}{c}\text { Males } \\
\text { VI }\end{array}$ \\
\hline Ln(Household Income p.h.) & $\begin{array}{r}-0.018 \\
(0.016)\end{array}$ & $\begin{array}{r}-0.021 \\
(0.016)\end{array}$ & $\begin{array}{r}-0.021 \\
(0.016)\end{array}$ & $\begin{array}{r}-0.019 \\
(0.016)\end{array}$ & $\begin{array}{r}-0.019 \\
(0.016)\end{array}$ & $\begin{array}{r}-0.019 \\
(0.016)\end{array}$ \\
\hline Married & $\begin{array}{r}-0.070 \\
(0.026)\end{array}$ & $\begin{array}{r}-0.072 \\
(0.026)\end{array}$ & $\begin{array}{r}-0.072 \\
(0.026)\end{array}$ & $\begin{array}{r}-0.070 \\
(0.026)\end{array}$ & $\begin{array}{r}-0.072 \\
(0.026)\end{array}$ & $\begin{array}{r}-0.070 \\
(0.026)\end{array}$ \\
\hline High stress & & $\begin{array}{r}-0.032 \\
(0.020)\end{array}$ & & & & \\
\hline Not playing a useful role & & & $\begin{array}{r}-0.041 \\
(0.020)\end{array}$ & & & \\
\hline Constantly under strain & & & & $\begin{array}{r}-0.018 \\
(0.019)\end{array}$ & & \\
\hline Unhappy or depressed & & & & & $\begin{array}{r}-0.020 \\
(0.021)\end{array}$ & \\
\hline Low belief in self-worth & & & & & & $\begin{array}{r}-0.007 \\
(0.033)\end{array}$ \\
\hline Age & $\begin{array}{r}0.006 \\
(0.001)\end{array}$ & $\begin{array}{r}0.005 \\
(0.001)\end{array}$ & $\begin{array}{r}0.006 \\
(0.001)\end{array}$ & $\begin{array}{r}0.005 \\
(0.001)\end{array}$ & $\begin{array}{r}0.005 \\
(0.001)\end{array}$ & $\begin{array}{r}0.006 \\
(0.001)\end{array}$ \\
\hline Education: Interm & $\begin{array}{r}-0.026 \\
(0.021)\end{array}$ & $\begin{array}{r}-0.027 \\
(0.021)\end{array}$ & $\begin{array}{r}-0.027 \\
(0.021)\end{array}$ & $\begin{array}{r}-0.026 \\
(0.021)\end{array}$ & $\begin{array}{r}-0.026 \\
(0.021)\end{array}$ & $\begin{array}{r}-0.026 \\
(0.021)\end{array}$ \\
\hline Education: Degree & $\begin{array}{r}-0.026 \\
(0.029)\end{array}$ & $\begin{array}{r}-0.025 \\
(0.029)\end{array}$ & $\begin{array}{r}-0.026 \\
(0.029)\end{array}$ & $\begin{array}{r}-0.026 \\
(0.029)\end{array}$ & $\begin{array}{r}-0.026 \\
(0.029)\end{array}$ & $\begin{array}{r}-0.026 \\
(0.029)\end{array}$ \\
\hline Smoker & $\begin{array}{r}0.040 \\
(0.020)\end{array}$ & $\begin{array}{r}0.043 \\
(0.020)\end{array}$ & $\begin{array}{r}0.043 \\
(0.020)\end{array}$ & $\begin{array}{r}0.041 \\
(0.020)\end{array}$ & $\begin{array}{r}0.043 \\
(0.020)\end{array}$ & $\begin{array}{r}0.041 \\
(0.020)\end{array}$ \\
\hline Health problems: 1 & $\begin{array}{r}0.027 \\
(0.018)\end{array}$ & $\begin{array}{r}0.028 \\
(0.018)\end{array}$ & $\begin{array}{r}0.028 \\
(0.018)\end{array}$ & $\begin{array}{r}0.028 \\
(0.018)\end{array}$ & $\begin{array}{r}0.028 \\
(0.018)\end{array}$ & $\begin{array}{r}0.027 \\
(0.018)\end{array}$ \\
\hline Health problems: 2 & $\begin{array}{r}0.047 \\
(0.026)\end{array}$ & $\begin{array}{r}0.050 \\
(0.027)\end{array}$ & $\begin{array}{r}0.052 \\
(0.027)\end{array}$ & $\begin{array}{r}0.049 \\
(0.026)\end{array}$ & $\begin{array}{r}0.048 \\
(0.026)\end{array}$ & $\begin{array}{r}0.048 \\
(0.026)\end{array}$ \\
\hline Health problems: 3 & $\begin{array}{r}0.085 \\
(0.041)\end{array}$ & $\begin{array}{r}0.095 \\
(0.044)\end{array}$ & $\begin{array}{r}0.098 \\
(0.044)\end{array}$ & $\begin{array}{r}0.087 \\
(0.042)\end{array}$ & $\begin{array}{r}0.089 \\
(0.042)\end{array}$ & $\begin{array}{r}0.085 \\
(0.042)\end{array}$ \\
\hline Health problems: 4 or more & $\begin{array}{r}0.147 \\
(0.065)\end{array}$ & $\begin{array}{r}0.161 \\
(0.068)\end{array}$ & $\begin{array}{r}0.166 \\
(0.069)\end{array}$ & $\begin{array}{r}0.159 \\
(0.068)\end{array}$ & $\begin{array}{r}0.160 \\
(0.069)\end{array}$ & $\begin{array}{r}0.148 \\
(0.065)\end{array}$ \\
\hline $\begin{array}{l}\text { Observations } \\
\text { Log-L } \\
\text { Pseudo } \mathrm{R}^{2}\end{array}$ & $\begin{array}{r}1155 \\
-326.0 \\
0.124 \\
\end{array}$ & $\begin{array}{r}1155 \\
-323.8 \\
0.130 \\
\end{array}$ & $\begin{array}{r}1155 \\
-323.5 \\
0.131 \\
\end{array}$ & $\begin{array}{r}1155 \\
-325.0 \\
0.127 \\
\end{array}$ & $\begin{array}{r}1155 \\
-325.1 \\
0.126 \\
\end{array}$ & $\begin{array}{r}1155 \\
-325.7 \\
0.125 \\
\end{array}$ \\
\hline
\end{tabular}

1. See notes Table $1 \mathrm{a}$.

2. High stress denotes an individual who responds to 4 or more of the 12 GHQ questions negatively (see Bowling, 1997). Playing a useful role, Constantly under strain, Unhappy or depressed, and Believe in self-worth are all variables coded 1 if the individual answers negatively. 
TABLE 5b

Female Mortality and Marital Status

Those aged 40 to 65

Dependent Variable: Deceased between 1992 and 2001

\begin{tabular}{|c|c|c|c|c|c|c|}
\hline \multirow{2}{*}{ Regressors (1991) } & Females & Females & Females & Females & Females & Females \\
\hline & $I$ & II & III & $I V$ & $V$ & $V I$ \\
\hline \multirow[t]{2}{*}{ Ln(Household Income p.h.) } & 0.002 & 0.003 & 0.005 & 0.003 & 0.003 & 0.003 \\
\hline & (0.013) & $(0.013)$ & $(0.013)$ & $(0.013)$ & $(0.013)$ & $(0.013)$ \\
\hline \multirow[t]{2}{*}{ Married } & -0.014 & -0.012 & -0.009 & -0.013 & -0.013 & -0.013 \\
\hline & $(0.016)$ & $(0.016)$ & $(0.015)$ & $(0.016)$ & $(0.016)$ & $(0.016)$ \\
\hline \multirow[t]{2}{*}{ High stress } & & 0.033 & & & & \\
\hline & & $(0.021)$ & & & & \\
\hline Not playing a useful role & & & $\begin{array}{r}0.064 \\
(0.026)\end{array}$ & & & \\
\hline Constantly under strain & & & & $\begin{array}{r}0.009 \\
(0.016)\end{array}$ & & \\
\hline Unhappy or depressed & & & & & $\begin{array}{r}0.023 \\
(0.019)\end{array}$ & \\
\hline Low belief in self-worth & & & & & & $\begin{array}{r}0.066 \\
(0.036)\end{array}$ \\
\hline \multirow[t]{2}{*}{ Age } & 0.007 & 0.007 & 0.007 & 0.007 & 0.007 & 0.007 \\
\hline & $(0.001)$ & $(0.001)$ & $(0.001)$ & $(0.001)$ & $(0.001)$ & $(0.001)$ \\
\hline \multirow[t]{2}{*}{ Education: Intermediate } & -0.003 & -0.004 & -0.004 & -0.004 & -0.003 & -0.003 \\
\hline & $(0.017)$ & $(0.017)$ & $(0.017)$ & $(0.017)$ & $(0.017)$ & $(0.017)$ \\
\hline \multirow[t]{2}{*}{ Education: Degree } & -0.020 & -0.020 & -0.018 & -0.021 & -0.019 & -0.020 \\
\hline & $(0.025)$ & $(0.025)$ & $(0.025)$ & $(0.025)$ & $(0.025)$ & $(0.025)$ \\
\hline \multirow[t]{2}{*}{ Smoker } & 0.012 & 0.010 & 0.009 & 0.011 & 0.011 & 0.012 \\
\hline & $(0.015)$ & $(0.015)$ & $(0.015)$ & $(0.015)$ & $(0.015)$ & $(0.015)$ \\
\hline \multirow[t]{2}{*}{ Health problems: 1} & -0.005 & -0.006 & -0.006 & -0.005 & -0.006 & -0.006 \\
\hline & $(0.014)$ & $(0.014)$ & $(0.014)$ & $(0.014)$ & $(0.014)$ & $(0.014)$ \\
\hline \multirow[t]{2}{*}{ Health problems: 2} & 0.008 & 0.003 & 0.001 & 0.007 & 0.005 & 0.005 \\
\hline & $(0.018)$ & $(0.018)$ & $(0.018)$ & $(0.018)$ & $(0.018)$ & $(0.018)$ \\
\hline \multirow[t]{2}{*}{ Health problems: 3} & 0.041 & 0.033 & 0.028 & 0.039 & 0.036 & 0.036 \\
\hline & $(0.028)$ & $(0.027)$ & $(0.026)$ & $(0.028)$ & $(0.028)$ & $(0.027)$ \\
\hline \multirow[t]{2}{*}{ Health problems: 4 or more } & 0.081 & 0.057 & 0.046 & 0.075 & 0.065 & 0.052 \\
\hline & $(0.046)$ & $(0.043)$ & $(0.040)$ & $(0.046)$ & $(0.045)$ & $(0.042)$ \\
\hline Observations & 1355 & 1355 & 1355 & 1355 & 1355 & 1355 \\
\hline Log-L & -298.0 & -296.5 & -293.7 & -297.8 & -297.2 & -295.7 \\
\hline Pseudo $\mathrm{R}^{2}$ & 0.134 & 0.138 & 0.146 & 0.134 & 0.136 & 0.141 \\
\hline
\end{tabular}

1. See notes Table 1a.

2. High stress denotes an individual who responds to 4 or more of the 12 GHQ questions negatively (see Bowling, 1997). Playing a useful role, Constantly under strain, Unhappy or depressed, and Believe in self-worth are all variables coded 1 if the individual answers negatively. 